DOI.

https://doi.org/10.22219/fths.v3i1

Received: Desember 2019

Accepted: Januari 2020

Available online: Februari 2020

\title{
Studi Pembuatan Minuman Serbuk Ekstrak Mawar Merah dengan Metode Foam Mat Drying
}

\author{
Nisa Rahmawati ${ }^{1}$, Elfi Anis Saati ${ }^{*}$, Mochammadi Wachid ${ }^{1}$ \\ Hanif Alamudin Manshur ${ }^{1}$ \\ ${ }^{1}$ Program Studi Teknologi Pangan, Fakultas Pertanian Peternakan, Universitas \\ MuhammadiyahMalang, Malang, Indonesia \\ *Corresponding author email: elfi@umm.ac.id
}

\begin{abstract}
Foam mat drying is a drying method that produced powder with better quality compared to conventional drying. The research aimed to analyze the effect of egg albumen concentration as foaming agent and the addition of different types sugar on red rose instan powder properties. Nested design by two factor with 3 replications were applied in this research. The first was concentration of egg albumen as the nest with 3 levels $(6 \%, 8 \%$ and 10\%) and the second was the addition type of sugar as the nested part with 3 types (granulated sugar, corn sugar and palm sugar). The results showed that the effect of concentration egg albumen significant $(p<0.05)$ on the water content, $p H$, total dissolved solids, anthocyanin levels, antioxidant activity, color intensity ( $L$ and $a+$ ) and appearance. The different types of sugar addition gave significant effect $(p<0.05)$ on water content,total dissolved solids, appearance, aroma and taste. Water content and ash content of red rose instan powder has been according to the Indonesian National Standard (SNI 01-4320-1996) instant powder drink. The best treatment proved by concentration of $6 \%$ egg albumen and the addition of corn sugar with the value of moisture content of $2.46 \%$, ash content of $0.42 \%$, solubility $86.47 \%$, water absorption 35.44 $\%$, pH 4.11, total dissolved solid $10.2^{\circ}$ Brix, anthocyanin level $77.24 \mathrm{mg} / \mathrm{L}$, antioxidant activity $69.82 \%$, color intensity ( $L: 49.8$ and $a+: 36.4$ ) and hedonic tests (appearance, aroma adn taste) of red rose instan powder were accepted by panelist.
\end{abstract}

Keywords : egg albumen, foam mat drying, red rose instan powder, sugar

\section{PENDAHULUAN}

Kandungan antosianin ekstrak pekat mawar merah terbukti dapat berperan sebagai antioksidan. Pemberian antosianin ekstrak pekat mawar pada tikus terbukti menurunkan nilai SGOT dari 117,542 U/I menjadi 18, $267 \mathrm{U} / \mathrm{I}$ dibandingkan vitamin A dan C (Saati, 2016), namun estrak pekat mawar dalam bentuk cair memiliki kelemahan saat disimpan dalam jangka waktu cukup lama, 
oleh karena itu, salah satu upaya untuk memperpanjang umur simpannya yaitu dengan mengolah menjadi serbuk.

Serbuk dapat diproduksi dengan mudah melalui proses pengeringan konvensional seperti kabinet, namun pengeringan tersebut membutuhkan waktu lama yang dapat mempengaruhi stabilitas antosianin. Foam mat drying dapat digunakan sebagai metode pengeringan lain untuk pengolahan produk serbuk yaitu dengan penambahan agen pembusa ke bahan yang dapat memperbesar luas permukaan sehingga pengeringan lebih cepat. Pengeringan pulp mangga dengan agen pembusa putih telur $10 \%$ dikeringkan pada $60{ }^{\circ} \mathrm{C}$ dapat mempertahankan kandungan biokimianya dibandingkan putih telur $15 \%$ (Rajkumar et al., 2007).

Oleh karena itu, dalam penelitian ini digunakan konsentrasi putih telur lebih rendah yaitu $6 \%, 8 \%$ dan $10 \%$ yang diharapkan dapat menghasilkan serbuk dengan mutu yang baik. Serbuk hasil pengeringan dalam penelitian ini selanjutnya dikembangkan menjadi produk minuman serbuk dengan ditambahkan bahan pamanis alami, meliputi gula pasir, gula jagung dan gula aren, agar produk yang dihasilkan tidak hanya rasa yang enak, tetapi dapat membawa dampak positif pada kesehatan serta meminimalisir penggunaan bahan pemanis sintetis.

\section{METODE PENELITIAN}

\section{Bahan}

Bahan yang digunakan antara lain bunga mawar merah tabur dengan umur simpan 1 hari yang diperoleh dari Pasar Besar Malang.

\section{Alat}

Alat yang digunakan antara lain, mixer merek maspion, cabinet dryer, timbangan analitik merek pioner Ohaus PA413, spectrofotometer UV - Visible tipe UV-1800 merek Shimadzu, color reader CR-10 merek Konica Minolta, handrefraktometer tipe N1 merek Atago.

\section{Pembuatan minuman serbuk mawar merah}

Mahkota mawar sebanyak 90 gram dihancurkan, ditambahkan pelarut aquadest : asam sitrat (98: 2) $300 \mathrm{ml}$. Campuran dimaserasi selama 1-2 jam pada suhu $10^{\circ} \mathrm{C}$. Filtrat disaring (Saati, 2012). $100 \mathrm{ml}$ ekstrak mawar merah ditambahkan putih telur sesuai perlakuan dan 10 gram maltodekstrin. Campuran tersebut dikocok hingga terbentuk busa. Busa dikeringkan dengan ketebalan $0,5 \mathrm{~cm}$ dengan suhu $60^{\circ} \mathrm{C}$ selama 4 jam. Serbuk hasil pengeringan dihaluskan, dilakukan pengayakan dan ditimbang. Serbuk ditambahkan gula sesuai perlakuan (gula pasir dan gula aren $85 \%$ b/b, sedangkan gula jagung 47 $\% \mathrm{~b} / \mathrm{b}$ ). Campuran dihomogenkan.

\section{Parameter Penelitian}

Minuman serbuk ekstrak mawar merah dianalisis secara fisik, kimia dan organoleptik. 


\section{Rancangan Percobaan dan Analisa Data}

Rancangan penelitian yang digunakan adalah rancangan tersarang (nested) yang tersusun atas dua faktor, faktor pertama yaitu konsentrasi putih telur terdiri dari 3 level $(6 \%, 8 \%$ dan $10 \%)$ sebagai sarang, sedangkan faktor kedua yaitu penambahan jenis gula terdiri dari 3 level (gula pasir, gula jagung dan gula aren) sebagai tersarang. Data hasil pengamatan dianalisis ANOVA $(p<0,05)$ dan uji lanjut BNJ $\alpha=5 \%$. Pemilihan perlakuan terbaik dilakukan dengan metode Indeks Efektifitas De Garmo, selanjutnya dilakukan uji perbandingan (uji t $\mathrm{p}<0,05$ ) antara perlakuan terbaik dengan kontrol (minuman serbuk ektrak mawar merah dengan pengeringan kabinet selama 23 jam pada suhu $50^{\circ} \mathrm{C}$ tanpa agen pembusa).

\section{HASIL DAN PEMBAHASAN}

\section{Kadar Air}

Berdasarkan hasil analisis ragam, konsentrasi putih telur yang berbeda dan penambahan jenis gula yang tersarang pada konsentrasi putih telur berpengaruh nyata terhadap kadar air minuman serbuk ekstrak mawar merah.

Tabel 1 Kadar air Minuman Serbuk Ekstrak Mawar Merah

\begin{tabular}{ccc}
\hline Konsentrasi Putih Telur (\%) & Jenis Gula & Kadar air (\%) \\
\hline \multirow{2}{*}{6} & Pasir & $1,85^{\mathrm{b}}$ \\
\cline { 2 - 3 } & Jagung & $2,46^{\mathrm{d}}$ \\
\cline { 2 - 3 } & Aren & $3,00^{\mathrm{f}}$ \\
\cline { 2 - 3 } 8 & Pasir & $1,80^{\mathrm{ab}}$ \\
\cline { 2 - 3 } & Jagung & $2,34^{\mathrm{c}}$ \\
\cline { 2 - 3 } & Aren & $3,07^{\mathrm{f}}$ \\
\hline \multirow{2}{*}{10} & Pasir & $1,75^{\mathrm{a}}$ \\
& Jagung & $2,28^{\mathrm{c}}$ \\
& Aren & $2,99^{\mathrm{e}}$ \\
\hline
\end{tabular}

Nilai rata-rata yang diikuti oleh notasi huruf yang sama tidak berbeda nyata menurut uji BNJ a $=5 \%$.

Minuman serbuk yang diberi putih telur $6 \%$, $8 \%$ dan $10 \%$ dengan penambahan gula pasir, gula jagung dan gula aren hasilnya berbeda nyata. Semakin tinggi konsentrasi putih telur, kadar air semakin rendah. Busa yang dihasilkan dapat memperluas luas permukaan bahan sehingga pada saat proses pengeringan, penguapan air lebih mudah dan cepat. Hal ini sesuai dengan Shaari et al., (2017), pengeringan puree nanas dengan putih telur $5 \%-20 \%$ kadar airnya mengalami penurunan seiring peningkatan konsentrasi putih telur.

Perlakuan penambahan gula pasir menghasilkan kadar air paling rendah sedangkan gula aren paling tinggi. Perbedaan nilai kadar air tersebut 
disebabkan oleh kandungan air dari masing-masing gula yang ditambahkan. Kadar air minuman serbuk ekstrak mawar merah yang dihasilkan rata-rata sudah memenuhi SNI kadar air minuman serbuk instan yaitu maks. $3 \%$.

\section{Kadar Abu, Kelarutan dan Daya Serap Air}

Berdasarkan hasil analisis ragam, konsentrasi putih telur yang berbeda dan penambahan jenis gula yang tersarang pada konsentrasi putih telur tidak berpengaruh nyata terhadap kadar abu, kelarutan dan daya serap air minuman serbuk ekstrak mawar merah.

a

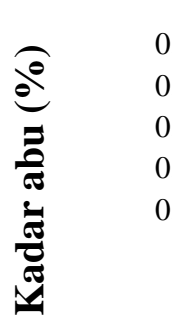

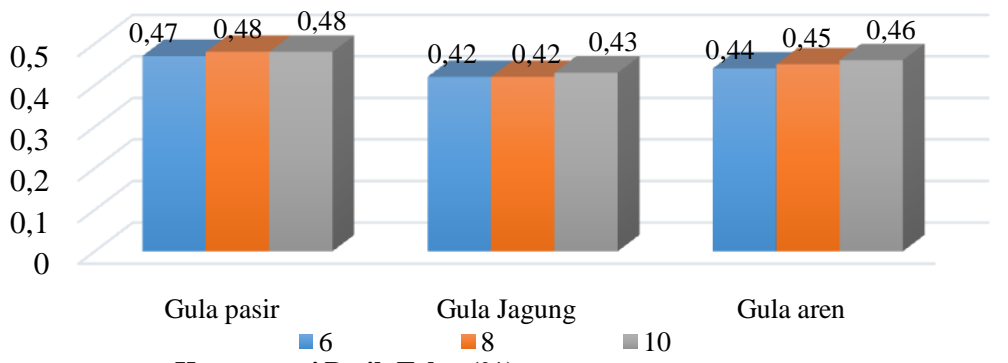

Konsentrasi Putih Telur (\%)

$\mathrm{b}$

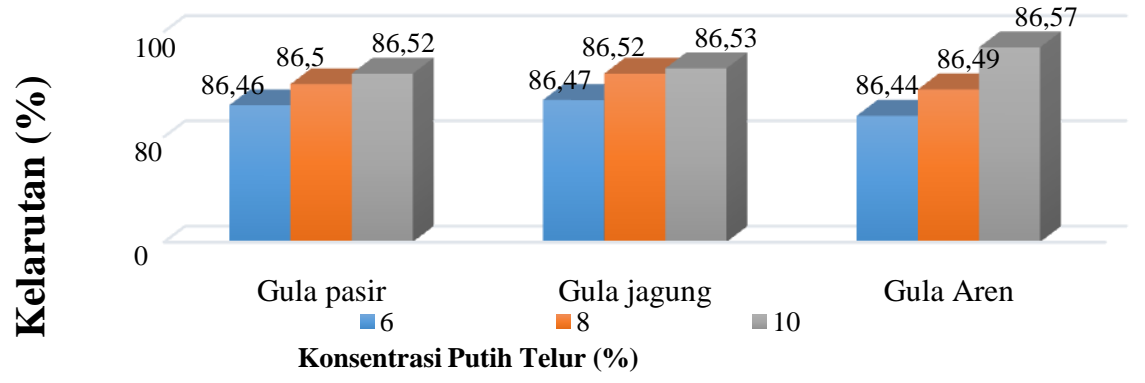

$\mathrm{c}$

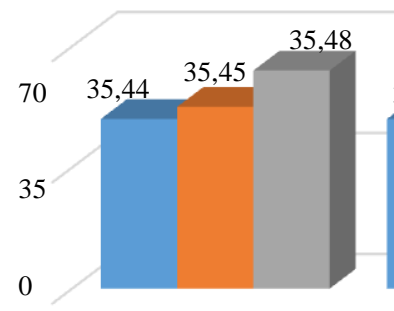

Gula pasir

$$
6
$$

Konsentrasi Putih Telur (\%)

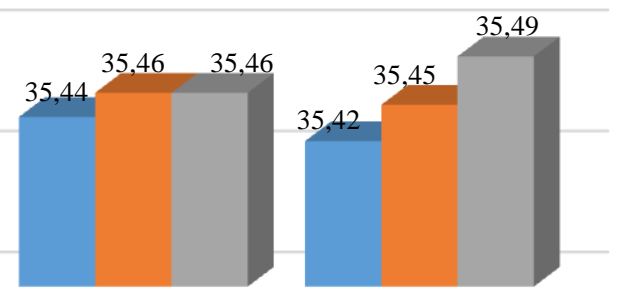

Gula Aren

Gambar 1. Histogram (a) Kadar Abu, (b) Kelarutan dan (c) Daya Serap Air Minuman Serbuk Ekstrak Mawar Merah

Gambar 1a. menunjukkan histogram kadar abu minuman serbuk ekstrak mawar merah, trend histogram menunjukkan semakin tinggi konsenstrasi putih telur, kadar abu mengalami peningkatan. Hal ini sesuai dengan penelitian Li et al., (2016) kadar abu tepung jagung mengalami peningkatan seiring meningkatnya konsentrasi putih telur. Penambahan putih telur dapat 
meningkatkan kandungan mineral karena putih telur mengandung beberapa mineral seperti besi, fosfor, kalsium, magnesium,kalium dan lainnya (American Egg Board, 2006).

Gambar 1b. Menunjukkan kelarutan minuman serbuk ekstrak mawar merah, trend histogram menunjukkan semakin tinggi konsentrasi putih telur, kelarutan mengalami peningkatan. Putih telur yang meningkat membuat ekspansi busa semakin besar yang menyebakan bubuk hasil pengeringan memiliki kadar air lebih rendah dan luas permukaan besar sehingga tingkat pengikatan air oleh bubuk semakin tinggi (Fazaeli et al., 2012).

Gambar 1c. menunjukkan histogram daya serap air minuman serbuk esktrak mawar merah, trend histogram menunjukkan semakin tinggi konsentrasi putih telur, daya serap air mengalami peningkatan. Hal ini sesuai dengan penelitian (Shaari et al., (2017), meningkatnya konsentrasi putih telur dari $5 \%-20 \%$, daya serap air bubuk nanas meningkat, karena serbuk bersifat lebih porous. Daya serap air juga dapat dipengaruhi oleh gula pada produk, karena gula bersifat higroskopis.

\section{Nilai $\mathrm{pH}$}

Berdasarkan hasil analisis ragam, konsentrasi putih telur yang berbeda berpengaruh nyata terhadap $\mathrm{pH}$ sedangkan penambahan jenis gula yang tersarang pada konsentrasi putih telur tidak berpengaruh nyata terhadap $\mathrm{pH}$ minuman serbuk ekstrak mawar merah.

Tabel 2. pH Minuman Serbuk Ekstrak Mawar Merah dengan Konsentrasi Putih Telur yang Berbeda

\begin{tabular}{cc}
\hline Konsentrasi Putih Telur (\%) & $\mathrm{pH}$ \\
\hline 6 & $4,11^{\mathrm{a}}$ \\
8 & $4,26^{\mathrm{b}}$ \\
10 & $4,48^{\mathrm{c}}$ \\
\hline
\end{tabular}

Nilai rata-rata yang diikuti oleh notasi huruf yang sama tidak berbeda nyata menurut uji BNJ a $=5 \%$.

$\mathrm{pH}$ minuman serbuk dengan pemberian putih telur $6 \%$ berbeda nyata dengan konsentrasi $8 \%$ dan $10 \%$. Nilai $\mathrm{pH}$ yang dihasilkan berkisar pada nilai 4, yang menunjukkan bahwa minuman serbuk ekstrak mawar merah memiliki rasa cukup asam. Keasamaan tersebut disebabkan karena adanya kandungan asam-asam organik pada bunga mawar dan asam sitrat yang ditambahkan pada saat proses ekstrasi bunga mawar.

Penambahan putih telur dapat meningkatkan nilai $\mathrm{pH}$. Semakin tinggi konsentrasi putih telur, nilai $\mathrm{pH}$ semakin meningkat. Hal ini dapat disebabkan karena putih telur memiliki $\mathrm{pH}$ yang bersifat basa yaitu 7,78 (Agustina et al., 2014). 


\section{Total Padatan Terlarut}

Berdasarkan hasil analisis ragam, konsentrasi putih telur yang berbeda dan penambahan jenis gula yang tersarang pada konsentrasi putih telur berpengaruh nyata terhadap total padatan terlarut minuman serbuk ekstrak mawar merah.

Tabel 3. Total Padatan Terlarut Minuman Serbuk Ekstrak Mawar Merah

\begin{tabular}{clc}
\hline Konsentrasi Putih Telur (\%) & Jenis Gula & TPT $\left({ }^{\circ}\right.$ Brix $)$ \\
\hline \multirow{2}{*}{8} & Pasir & $15^{\mathrm{c}}$ \\
& Jagung & $10,2^{\mathrm{a}}$ \\
& Aren & $16,7^{\mathrm{e}}$ \\
& Pasir & $15,5^{\mathrm{d}}$ \\
& Jagung & $10,5^{\mathrm{ab}}$ \\
& Aren & $17_{\mathrm{ef}}$ \\
& Pasir & $15,5^{\mathrm{d}}$ \\
& Jagung & $10,8^{\mathrm{b}}$ \\
& Aren & $17,3^{\mathrm{f}}$ \\
\hline
\end{tabular}

Nilai rata-rata yang diikuti oleh notasi huruf yang sama tidak berbeda nyata menurut uji BNJ $\alpha$ $=5 \%$.

Total padatan terlarut minuman serbuk yang diberi perlakuan putih telur 6 $\%, 8 \%$ dan $10 \%$ dengan penambahan gula pasir, gula jagung dan gula aren hasilnya berbeda nyata. Semakin tinggi konsentrasi putih telur, total padatan terlarut mengalami peningkatan. Putih telur merupakan protein globuler yang larut dan terkoagulasi oleh panas sehingga saat terkena air mudah larut dan meningkatkan total padatan terlarut bahan. Putih telur terdiri dari 88,57 \% air dan sisanya adalah padatan (Koswara, 2009).

Penambahan gula pasir dan gula aren menghasilkan total padatan terlarut lebih tinggi dibanding gula jagung. Hal ini disebakan karena gula pasir dan gula aren merupakan gula disakarida yaitu sukrosa yang tersusun atas glukosa dan fruktosa, sedangkan gula jagung merupakan jenis gula kelompok monosakarida yang hanya tersusun atas fruktosa saja (Darwin, 2013).

\section{Kadar Antosianin}

Berdasarkan hasil analisis ragam, konsentrasi putih telur yang berbeda berpengaruh nyata terhadap kadar antosianin, sedangkan penambahan jenis gula yang tersarang pada konsentrasi putih telur tidak berpengaruh nyata terhadap kadar antosianin minuman serbuk ekstrak mawar merah. 
Tabel 4 Kadar Antosianin Minuman Serbuk Ekstrak Mawar Merah dengan Konsentrasi Putih Telur yang Berbeda

\begin{tabular}{cc}
\hline Konsentrasi Putih Telur (\%) & Kadar Antosianin $(\mathrm{mg} / \mathrm{L})$ \\
\hline 6 & $77,19^{\mathrm{c}}$ \\
8 & $71,73^{\mathrm{b}}$ \\
10 & $68,66^{\mathrm{a}}$ \\
\hline
\end{tabular}

Nilai rata-rata yang diikuti oleh notasi huruf yang sama tidak berbeda nyata menurut uji BNJ a $=5 \%$.

Kadar antosiani minuman serbuk dengan pemberian putih telur $6 \%, 8 \%$ dan $10 \%$ hasilnya berbeda nyata. Semakin tinggi konsentrasi putih telur, kadar antosianin mengalami penurunan. Hal ini disebabkan karena semakin tinggi konsentrasi putih telur dapat menghasilkan ekspansi busa dan luas permukaan bahan yang semakin besar, sehingga menyebabkan kontak panas pada saat proses pengeringan dengan bahan semakin mudah.

Perlakuan panas dapat menyebabkan stabilitas atau kesetimbangan senyawa antosianin, mengalami perubahan menuju ke bentuk yang tidak berwarna, yaitu jenis basa karbinol dan kalkon. Kerusakan antosianin akibat pemanasan ini dapat terjadi melalui hidrolisis ikatan glikosidik antosianin sehingga menghasilkan aglikon-aglikon yang tidak stabil, kemudian cincin aglikon terbuka membentuk gugus karbinol dan kalkon, yang ditandai dengan hilangnya warna pigmen antosianin (Yoanista dan Herni, 2014).

\section{Aktivitas Antioksidan}

Berdasarkan hasil analisis ragam, konsentrasi putih telur yang berbeda berpengaruh nyata terhadap aktivitas antioksidan, sedangkan penambahan jenis gula yang tersarang pada konsentrasi putih telur tidak berpengaruh nyata terhadap aktivitas antioksidan minuman serbuk ekstrak mawar merah.

Tabel 5 Aktivitas Antioksidan Minuman Serbuk Ekstrak Mawar Merah dengan Konsentrasi Putih Telur yang Berbeda

\begin{tabular}{cc}
\hline Konsentrasi Putih Telur (\%) & Aktivitas Antioksidan (\%) \\
\hline 6 & $69,87^{\mathrm{b}}$ \\
8 & $69,48^{\mathrm{b}}$ \\
10 & $68,69^{\mathrm{a}}$ \\
\hline
\end{tabular}

Nilai rata-rata yang diikuti oleh notasi huruf yang sama tidak berbeda nyata menurut uji BNJ a $=5 \%$.

Aktivitas antioksidan minuman serbuk dengan pemberian putih telur $6 \%$ tidak berbeda nyata dengan konsentrasi $8 \%$, namun berbeda nyata dengan konsentrasi $10 \%$. Semakin tinggi konsentrasi putih telur, aktivitas antioksidan mengalami penurunan. Hal ini sesuai dengan Joshua dan Obafemi, (2017), 
peningkatan konsentrasi putih telur $5 \%-15 \%$ menyebabkan penurunan nilai retensi vitamin $\mathrm{C}$ sebagai antioksidan pada bubuk tomat

Pengeringan busa dengan kosentrasi putih telur yang lebih tinggi dapat memudahkan penguapan airnya karena luas permukaan besar, hal tersebut menyebabkan komponen bioktif yang berkontribusi sebagai antioksidan juga ikut teruapkan bersama uap air. Kandungan antioksidan dalam minuman serbuk ekstrak mawar dapat dipengaruhi oleh kandungan senyawa antosianin, vitamin B dan C, tanin dan minyak atsiri (Saati, 2012).

\section{Intensitas Warna}

Berdasarkan hasil analisis ragam, konsentrasi putih telur yang berbeda dan penambahan jenis gula yang tersarang pada konsentrasi putih telur berpengaruh nyata terhadap tingkat kecerahan dan kemerahan minuman serbuk ekstrak mawar merah.

Tabel 6 Intensitas Warna Minuman Serbuk Ekstrak Mawar Merah

\begin{tabular}{|c|c|c|c|}
\hline Konsentrasi Putih Telur (\%) & Jenis Gula & $\mathrm{L}$ & $a+$ \\
\hline \multirow{3}{*}{6} & Pasir & $46,8^{c}$ & $36,6^{f}$ \\
\hline & Jagung & 49,8 e & 36,4 cd \\
\hline & Aren & $45^{\text {a }}$ & 28,4 b \\
\hline \multirow{3}{*}{8} & Pasir & $47,3 \mathrm{~d}$ & 35,8 ef \\
\hline & Jagung & $50,2^{f}$ & $35,3 \mathrm{~cd}$ \\
\hline & Aren & $45,5 \mathrm{~b}$ & 27,8 ab \\
\hline \multirow{3}{*}{10} & Pasir & $47,5^{d}$ & 35,3 de \\
\hline & Jagung & $50,6 \mathrm{~g}$ & $34,8^{c}$ \\
\hline & Aren & $45,8^{\mathrm{b}}$ & $27,3^{\text {a }}$ \\
\hline
\end{tabular}

Nilai rata-rata yang diikuti oleh notasi huruf yang sama tidak berbeda nyata menurut uji BNJ a $=5 \%$.

Tingkat kecerahan dan kemerahan minuman serbuk yang diberi putih telur $6 \%$, $8 \%$ dan $10 \%$ dengan penambahan gula pasir, gula jagung dan gula aren hasilnya berbeda nyata. Semakin tinggi konsentrasi putih telur luas permukaan bahan semakin luas menyebabkan proses penguapan air lebih cepat sehingga tingkat kecerahan meningkat (warna menjadi pudar) dan kemerahan menurun. Tingkat kemerahan menurun akibat degradasi antosianin oleh suhu panas selama pengeringan.

Penambahan jenis gula yang berbeda menghasilkan tingkat kecerahan dan kemerahan yang berbeda. Hal ini dapat disebabkan karena perbedaan secara fisik berupa warna dari masing-masing gula yang ditambahkan. Gula aren cenderung berwarna coklat kekuningan, sedangkan gula pasir dan gula jagung berwarna cerah. 


\section{Kenampakan}

Berdasarkan hasil analisis ragam, konsentrasi putih telur yang berbeda dan penambahan jenis gula yang tersarang pada konsentrasi putih telur berpengaruh nyata terhadap kenampkan minuman serbuk ekstrak mawar merah.

Tabel 7 Skoring KenampakanMinuman Serbuk Ekstrak Mawar Merah

\begin{tabular}{ccc}
\hline Konsentrasi Putih Telur (\%) & Jenis Gula & Skoring Kenampakan \\
\hline \multirow{2}{*}{6} & Pasir & $6,27^{\mathrm{e}}$ \\
\cline { 2 - 3 } & Jagung & $5,70^{\mathrm{de}}$ \\
\cline { 2 - 3 } & Aren & $3,80^{\mathrm{b}}$ \\
\hline \multirow{2}{*}{8} & Pasir & $5,00^{\mathrm{cd}}$ \\
\cline { 2 - 3 } & Jagung & $5,50^{\mathrm{cd}}$ \\
\cline { 2 - 3 } & Aren & $3,30^{\mathrm{ab}}$ \\
\hline \multirow{2}{*}{10} & Pasir & $4,77^{\mathrm{c}}$ \\
& Jagung & $5,23^{\mathrm{cd}}$ \\
\cline { 2 - 3 } & Aren & $2,87^{\mathrm{a}}$ \\
\hline
\end{tabular}

Nilai rata-rata yang diikuti oleh notasi huruf yang sama tidak berbeda nyata menurut uji BNJ $\alpha$ $=5 \%$.

Kenampakan minuman serbuk ekstrak mawar merah yang diberi putih telur $6 \%, 8 \%$ dan $10 \%$ dengan penambahan gula pasir tidak berbeda nyata dengan penambahan gula jagung, namun berbeda nyata dengan gula aren. Minuman serbuk yang ditambahkan gula pasir dan gula jagung memiliki kenampakan agak menarik-cukup menarik. Minuman serbuk ekstrak mawar merah yang ditambahkan gula aren menurut panelis kurang menarik karena warnanya yang lebih gelap. Warna minuman serbuk ekstrak bunga mawar menjadi gelap disebabkan karena penambahan gula aren, dimana gula aren secara fisik memiliki warna yang gelap yaitu coklat kekuningan.

\section{Aroma}

Berdasarkan hasil analisis ragam, konsentrasi putih telur yang berbeda tidak berpengaruh nyata terhadap aroma, sedangkan penambahan jenis gula yang tersarang pada konsentrasi putih telur berpengaruh nyata terhadap aroma minuman serbuk ekstrak mawar merah. 
Tabel 8 Skoring Aroma Minuman Serbuk Ekstrak Mawar Merah

\begin{tabular}{ccc}
\hline Konsentrasi Putih Telur (\%) & Jenis Gula & Skoring Aroma \\
\hline \multirow{2}{*}{6} & Pasir & $4,57^{\mathrm{ab}}$ \\
\cline { 2 - 3 } & Jagung & $5,53^{\mathrm{b}}$ \\
\cline { 2 - 3 } & Aren & $3,86^{\mathrm{ab}}$ \\
\hline \multirow{2}{*}{8} & Pasir & $4,27^{\mathrm{ab}}$ \\
\cline { 2 - 3 } & Jagung & $5,5^{\mathrm{ab}}$ \\
\cline { 2 - 3 } & Aren & $3,63^{\mathrm{ab}}$ \\
\hline \multirow{2}{*}{10} & Pasir & $4,1^{\mathrm{ab}}$ \\
& Jagung & $5,27 \mathrm{~b}$ \\
\cline { 2 - 3 } & Aren & $3,37^{\mathrm{a}}$ \\
\hline
\end{tabular}

Nilai rata-rata yang diikuti oleh notasi huruf yang sama tidak berbeda nyata menurut uji BNJ $\alpha$ $=5 \%$.

Aroma minuman serbuk ekstrak mawar merah dengan penambahan gula pasir tidak berbeda nyata dengan penambahan gula aren, namun berbeda nyata dengan penambahan gula jagung. Gula pasir dan gula aren memiliki skoring $3-4$ yang artinya aroma kurang sedap dan agak sedap, sedangkan gula jagung memiliki skoring rata-rata 5 yang artinya cukup sedap. Panelis lebih menyukai penambahan dengan gula jagung, karena memiliki aroma yang harum dibandingkan gula pasir dan gula aren, selain itu aroma tersebut juga dipengaruhi oleh aroma dari bunga mawar merah karena kandungan minyak atsirinya.

\section{Rasa}

Berdasarkan hasil analisis ragam, konsentrasi putih telur yang berbeda tidak berpengaruh nyata terhadap rasa, sedangkan penambahan jenis gula yang tersarang pada konsentrasi putih telur berpengaruh nyata terhadap rasa seduhan minuman serbuk ekstrak mawar merah.

Seduhan minuman serbuk ekstrak mawar merah dengan penambahan gula pasir tidak berbeda nyata dengan perlakuan gula jagung, namun berbeda nyata dengan perlakuan gula aren. Seduhan minuman serbuk ekstrak mawar merah yang ditambahkan gula jagung memiliki skoring rasa paling tinggi yaitu $5-6$ yang artinya cukup enak hingga enak (kombinasi manis dan segar), sedangkan gula aren menghasilkan skoring paling rendah yaitu 3 (kurang enak). Gula jagung dapat menghasilkan minuman yang cukup manis karena tingkat kemanisan gula jagung lebih tinggi 1,8 kali dibandingkan jenis gula biasa (Darwin, 2013). 
Tabel 9 Skoring Rasa Seduhan Minuman Serbuk Ekstrak Mawar Merah

\begin{tabular}{ccc}
\hline Konsentrasi Putih Telur (\%) & Jenis Gula & Skoring Rasa \\
\hline \multirow{2}{*}{6} & Pasir & $4,70^{\mathrm{b}}$ \\
\cline { 2 - 3 } & Jagung & $5,13^{\mathrm{bc}}$ \\
\cline { 2 - 3 } & Aren & $3,43^{\mathrm{a}}$ \\
\hline \multirow{2}{*}{8} & Pasir & $4,80^{\mathrm{b}}$ \\
\cline { 2 - 3 } & Jagung & $5,23^{\mathrm{bc}}$ \\
\cline { 2 - 3 } & Aren & $3,16^{\mathrm{a}}$ \\
\hline \multirow{2}{*}{10} & Pasir & $4,83^{\mathrm{b}}$ \\
& Jagung & $6,00^{\mathrm{c}}$ \\
\cline { 2 - 3 } & Aren & $3,10^{\mathrm{a}}$ \\
\hline
\end{tabular}

Nilai rata-rata yang diikuti oleh notasi huruf yang sama tidak berbeda nyata menurut uji BNJ $\alpha$ $=5 \%$.

\section{Penentuan Perlakuan Terbaik}

Berdasarkan hasil analisis indeks efektifitas, diperoleh hasil perlakuan terbaik yaitu putih telur $6 \%$ dengan penambahan gula jagung. Tabel 10 . menunjukkan hasil analisis indeks efektivitas.

Tabel 10 Hasil Perhitungan Indeks Efektivitas

\begin{tabular}{cccc}
\hline Konsentrasi Putih Telur (\%) & Jenis Gula & Nilai Hasil & Peringkat \\
\hline \multirow{3}{*}{6} & Pasir & 0,604 & 3 \\
\cline { 2 - 4 } & Jagung & 0,676 & 1 \\
\cline { 2 - 4 } & Aren & 0,435 & 7 \\
\hline \multirow{2}{*}{8} & Pasir & 0,521 & 5 \\
\cline { 2 - 4 } & Jagung & 0,62 & 2 \\
\cline { 2 - 4 } 10 & Aren & 0,361 & 8 \\
\hline \multirow{2}{*}{10} & Pasir & 0,444 & 6 \\
& Jagung & 0,526 & 4 \\
\hline & Aren & 0,307 & 9 \\
\hline
\end{tabular}

\section{Perbandingan Perlakuan Terbaik dengan Kontrol}

Berdasarkan hasil uji t $\mathrm{p}<0,05$ terdapat perbedaan pada sifat fisik, kimia dan organoleptik minuman serbuk ekstrak mawar merah perlakuan terbaik dengan kontrol. 
Tabel 11 Perbandingan Sifat Fisik Perlakuan Terbaik dengan Kontrol

\begin{tabular}{lccc}
\hline Parameter & \multicolumn{2}{c}{ Perlakuan } & \multirow{2}{*}{ Uji t 5 \% } \\
\cline { 2 - 3 } & Terbaik & Kontrol & \\
\hline Kelarutan & 86,47 & 73,85 & $*$ \\
Daya Serap & 35,44 & 14,70 & $*$ \\
L & 49,8 & 39,3 & $*$ \\
a & 36,4 & 17,4 & $*$ \\
\hline
\end{tabular}

Keterangan : * (terdapat perbedaan $\mathrm{p}<0,05)$

Tabel 11. menunjukkan perbedaan sifat fisik minuman serbuk perlakuan terbaik dengan kontrol. Perlakuan terbaik menghasilkan kelarutan dan daya serap air lebih tinggi dibandingkan kontrol karena adanya busa yang menyebakan udara terperangkap sehingga dihasilkan produk lebih porous yang membuat serbuk lebih mudah ditembus air. Tingkat kecerahan dan kemerahan perlakuan terbaik lebih tinggi dibandingkan kontrol, perlakuan pemanasan kontrol yang lebih lama menyebabkan tejadinya browning non enzimatis, sedangkan tingkat kemerahan disebabkan karena antosianin yang terdegradasi oleh pemanasan yang terlalu lama.

Tabel 12 Perbandingan Sifat Kimia Perlakuan Terbaik dengan Kontrol

\begin{tabular}{lccc}
\hline \multirow{2}{*}{ Parameter } & \multicolumn{2}{c}{ Perlakuan } & \multirow{2}{*}{ Uji t 5 \% } \\
\cline { 2 - 3 } & Terbaik & Kontrol & \\
\hline Kadar air & 2,46 & 4,07 & $*$ \\
Kadar abu & 0,42 & 0,27 & $*$ \\
pH & 4,11 & 2,99 & $*$ \\
TPT & 10,2 & 5,4 & $*$ \\
Antosianin & 77,24 & 11,84 & $*$ \\
Antioksidan & 69,82 & 13,10 & $*$ \\
\hline
\end{tabular}

Keterangan : * (terdapat perbedaan $\mathrm{p}<0,05)$

Tabel 12. menunjukkan perbedaan sifat kimia minuman serbuk perlakuan terbaik dengan kontrol. Perlakuan terbaik menghasilkan kadar air yang lebih rendah dibanding kontrol. Busa putih telur pada perlakuan terbaik dapat memperluas luas permukaan bahan sehingga penguapan air lebih maksimal dibanding kontrol tanpa agen pembusa. Perlakuan terbaik juga menghasilkan kadar abu lebih tinggi dibandingkan kontrol, karena adanya putih telur dapat meningkatkan kandungan mineral, sedangkan kontrol tidak ada penambahan putih telur.

Perlakuan terbaik minuman serbuk menghasilkan $\mathrm{pH}$ yang lebih tinggi dibandingkan kontrol. Perbedaan tersebut dikarenakan pada perlakuan terbaik terdapat penambahan putih telur yang bersifat basa. Total padatan terlarut perlakuan terbaik juga lebih tinggi dibanding kontrol. Penambahan putih telur 
dapat meningkatkan total padatan terlarut pada produk, sedangkan pada kontrol tidak ada penambahan putih telur.

Perlakuan terbaik minuman serbuk menghasilkan kadar antosianin dan aktvitas antioksidan yang lebih tinggi dibanding kontrol, hal ini disebabkan karena pengeringan pada perlakuan terbaik lebih cepat dibandingkan perlakuan kontrol. Semakin lama pemanasan, antosianin yang ada pada bahan akan semakin mudah terdegradasi oleh panas. Perlakuan terbaik dengan adanya penambahan busa dapat mempercepat pengeringan karena luas permukaan bahannya besar.

Tabel 13 Perbandingan Sifat Organoleptik Perlakuan Terbaik dengan Kontrol

\begin{tabular}{lccc}
\hline \multirow{2}{*}{ Parameter } & \multicolumn{2}{c}{ Perlakuan } & Uji t 5\% \\
\cline { 2 - 3 } & Terbaik & Kontrol & \\
\hline Kenampakan & 5,7 & 2,33 & $*$ \\
Aroma & 5,53 & 2,07 & $*$ \\
Rasa & 5,13 & 1,67 & $*$ \\
\hline
\end{tabular}

Keterangan : * (terdapat perbedaan $\mathrm{p}<0,05)$

Skoring kenampakan, aroma dan rasa perlakuan terbaik lebih tinggi dibandingkan kontrol. Perlakuan kontrol menghasilkan produk dengan aroma kenampakan yang tidak menarik, aroma yang tidak sedap dan rasa yang tidak enak. Perlakuan pemanasan yang terlalu lama pada kontrol mempengaruhi kenampakan, rasa dan aroma yang tidak disukai oleh panelis.

\section{KESIMPULAN}

Konsentrasi putih telur yang berbeda berpengaruh nyata terhadap kadar air, pH, total padatan terlarut, kadar antosianin, aktivitas antioksidan, intensitas warna (L dan a+) dan kenampakan minuman serbuk ekstrak mawar merah. Penambahan jenis gula yang tersarang pada konsentrasi putih telur berpengaruh nyata terhadap kadar air, total padatan terlarut, kenampakan, aroma dan rasa minuman serbuk ekstrak mawar merah. Kadar air dan kadar abu minuman serbuk ekstrak mawar merah telah memenuhi SNI 01-4320-1996 minuman serbuk instan, yaitu kadar air maks. $3 \%$ dan kadar abu maks. 1,5\%. Perlakuan konsentrasi putih telur $6 \%$ dengan penambahan gula jagung menghasilkan minuman serbuk ekstrak mawar merah dengan karakteristik yang terbaik, meliputi kadar air 2,46\%, kadar abu 0,42 \%, kelarutan 86,47\%, daya serap air $35,44 \%$, pH 4,11 , total padatan terlarut $10,2^{\circ}$ Brix, kadar antosianin $77,24 \mathrm{mg} / \mathrm{L}$, aktivitas antioksidan 69,82 \%, Intensitas warna (L : 49,8 dan a+ :36,4), kenampakan dengan skoring 5,7 (cukup menarik) aroma 5,53 (cukup sedap) dan rasa 5,13 (cukup enak). 


\section{REFERENSI}

Agustina, N., Imam, T., dan Djalal, R. 2014. Evaluasi sifat albumen telur (putih telur) ayam pasteurisasi ditinjau dari $\mathrm{pH}$, kadar air, sifat emulsi dan daya kembang Angel Cake. Jurnal Ilmu-ilmu Peternakan 23(2) 16-23.

Board, American Egg. 2006. The Incredible Edible Egg. US.

Darwin, P. 2013. Menikmati Gula Tanpa Rasa Takut. Sinar Ilmu, Perpustakaan Nasional.

Fazaeli, M., Emam-Djomeh, Z., Ashtari, A. K., \& Omid, M. 2012. Effect of spray drying conditions and feed composition on the physical properties of black mulberry juice powder. Food and Bioproducts Processing 90, 667-675.

Joshua, Olanrewaju Olaoye and Obafemi, Ibitayo Obajemihi. 2017. Drying rate and quality attributes of foam-mat dried tomato pulp. Ukrainian Food Journal Volume 6. Issues 2 .

Koswara, S. 2009. Teknologi Pengolahan Telur (Teori dan Praktek). Accessed Oktober 12, 2018. eBookPangan.com .

Li, Shing Teoh, Ola L, Shakirah A. 2016. Quality characteristics and volatile compounds of foam mat dried corn flour. Journal of Food Quality 456-464 .

Rajkumar, P,. Kailappan, R,. Viswanathan, R,. Raghavan, G.S.V. 2007. Drying Characteristics of Foamed Alphonso Mango Pulp in a Continous Type Foam Mat Dryer. J. Food Eng 79;1452-1459.

Saati, E.A. 2016. Antioxidant power of rose anthocyanin pigment. ARPN J. Eng. Appl. Sci. 11(17), 10201-1204.

Saati, E.A., Theovilla, R.R.D., Simon, B.W.,. 2012. Optimalisasi Fungsi Pigmen Bunga Mawar Sortiran sebagai Zat Pewarna Alami dan Bioaktif Pada Produk Industri. Jurnal Teknik Industri 12(2): 96-104.

Shaari, Nur Atika, Rabiha Sulaiman, Russly Abdul Rahman,Jamilah Bakar. 2017. Production of pineapple fruit (Ananas comosus) powder using foam mat drying: Effect of whipping time and egg albumen concentration. .J Food Process Preserv 1-10.

Yoanista, Ilus Kotan dan Heni, Kusriani R. 2014. Kajian Pustaka Antosianin dari Buah Djuwet atau Jamblang ((Syzygium cumini). Sekolah Tinggi Farmasi Bandung. 